\title{
Variaciones sobre el cristal
}

\section{Variations on the Glass}

\author{
Ana María LeYRa Soriano \\ Universidad Complutense de Madrid \\ aleyra@filos.ucm.es
}

Recibido: 23 de noviembre de 2010

Aceptado: 24 de noviembre de 2010

\section{Resumen}

La transparencia es una constante en la obra de Ramón Gaya. Pero no se trata sólo de una idea que bajo la forma del cristal, a partir de vasos, jarras, recipientes o espejos, se repite con inusitada fijeza en sus pinturas, sino también del empeño por hacer de su escritura una vía límpida de comunicar su pensamiento sobre el arte. Se perfila así toda una estrategia por parte del artista que nos invita a valorar su obra como una profunda y compleja reflexión, intencionalmente disimulada tras su apariencia de simplicidad, en torno a un realismo que, lejos de mostrarnos lo que está en el cuadro, nos interroga sobre las relaciones del arte con la naturaleza, con la vida y con el propio individuo, artista creador.

Palabras clave: transparencia, sentimiento, firma, escritura.

Sumario.- La noción de transparencia. Lo positivo y lo negativo de la transparencia. La escritura y la claridad/transparencia en el pensamiento español. El sentimiento de la pintura. Anónimo y doble firma. De la tachadura del nombre propio a su duplicación.

\begin{abstract}
Transparency is a constant feature in Ramón Gaya's work. But it is not just an idea that, in the shape of glass vases, mugs, cans or mirrors, is repeated in his paintings with an unusual insistence. It means also the effort to make his writing a clear way to communicate his thought on art. A complete strategy is then delineated by
\end{abstract}


the artist, who invites us to consider his work as a deep and complex reflection, deliberately hidden behind its apparent simplicity, through a realism that, far from showing us what is on the picture, arises the question on the relationship of art towards nature, life and towards the individual artist himself as a creator.

Keywords: transparency, feeling, signature, writing.

Summary.- The notion of transparency. The positive and negative side of transparency. Writing and Clearness/Transparency in the Spanish thought. The feeling of painting. Anonymous and double signature. From the erasure of the proper name to its duplication.

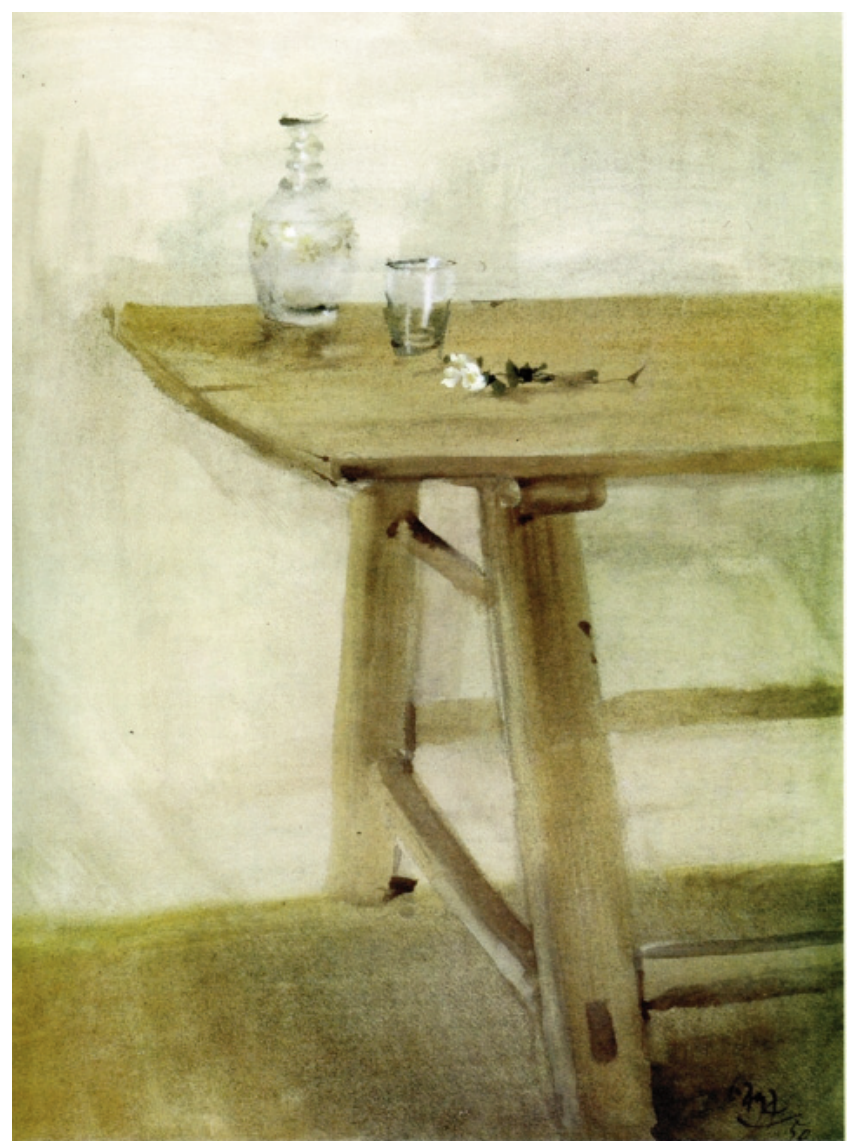

Fig. 1.- La mesa. Estudio de Salvador, 1950.

Gouache sobre papel. 60 × $44 \mathrm{~cm}$. Colección particular. 


\section{La noción de transparencia}

En una entrevista, realizada en Valencia por el profesor Nigel Dennis, Ramón Gaya nos ofrece una clarificadora descripción de su interés por esos objetos cristalinos que le fascinan:

N.D. ¿Y esa transparencia del cristal?

R.G. Bueno, lo pensé entonces mucho, por las veces que me preguntaban sobre ello. Yo no me lo preguntaba propiamente, asi de una manera espontánea, sino acuciado por las preguntas de los demás. A mí me bastaba con saber que esa transparencia me gustaba, que esa transparencia no era para mí solamente una maravilla, un fenómeno maravilloso, sino que me llevaba a otras cosas - a ver, por ejemplo, los objetos a través de esa transparencia. (...) Muchas veces he puesto frutos o flores detrás de esos vasos. No ya unas flores dentro sino detrás de un vaso. Y resulta que esas flores quedan... transformadas. Es decir que un cristal se abre sobre un abismo: el abismo de la transparencia. Alli en ese misterio, creo que se puede entrar como se puede entrar en un espejo también. Pero pensándolo más-porque siempre se le quedan a uno cosas en el tintero de la cabeza- he llegado a pensar que, quizá, esa transparencia del cristal era como una metáfora (...) y digo "quizá" porque no lo sé exactamente. Pero quizá esa transparencia sea involuntariamente una metáfora de la realidad misma. Es decir, para mí la realidad tiene cuerpo, tiene presencia, y además es al mismo tiempo transparente. Detrás de la realidad parece que se divisa algo, que se ve algo... Y entonces, sin saberlo muy a ciencia cierta, a mí, quizá, me atrae mucho el cristal o las cosas de vidrio, porque las veo como una metáfora de eso, de esa idea que tengo de la realidad... (Valencia, 1983)1

Y entonces pienso en Nietzsche. Es Nietzsche un autor familiar para Ramón, un compañero de viaje, no un discípulo, conocido y leído desde muy pronto y salvado de las manipulaciones, de los prejuicios. Pienso en su manera de entender el arte jugando con las palabras, obligándonos a pensar a saltos con sus aforismos, a romper con las cadenas dogmáticas que nos paralizan. Diríamos que Nietzsche impregna el pensamiento de nuestro pintor, pero no estoy hablando de influencia, de escuela, de ningún tipo de seguimiento, sino más bien de esa manera fecunda que hace que una lectura nos transforme y nos abra las puertas de un universo propio, si bien transfigurado, enriquecido por aportaciones innumerables.

Pienso en el fragmento $\mathrm{n}^{\circ} 796$ de La voluntad de poder, donde Nietzsche escribe: El fenómeno "artista" es bastante transparente. ${ }^{2}$ En este fragmento, en virtud

1 Gaya. R.: _ de viva voz. Entrevistas, (1977-1998). Selección y presentación de Nigel Dennis. Valencia, Pre-Textos, 2007, p. 241.

2 Nietzsche, F.: La voluntad de poderío. Obras Completas, (traducción de Eduardo Ovejero y Maury), vol. IV, editorial Aguilar, 1932, p. 307. Citamos por la primera edición de Aguilar con la traducción de Ovejero y Maury, ya que, aunque no hemos podido confirmarlo, suponemos que la edición pudo ser la conocida por Ramón Gaya en sus primeras lecturas de Nietzsche. 
de una fórmula tan concisa, recurriendo a la metáfora ${ }^{3}$, Nietzsche nos enfrenta a pensar el sentido de la transparencia en relación con el arte, sus cualidades, sus ventajas, su modo de relacionarse con los ojos que ven lo transparente.

Pues bien, el tema de la transparencia retorna una y otra vez a nosotros en los cuadros y en las páginas de Ramón Gaya, con una insistencia que matiza, introduciendo variaciones, el hilo conductor de su pensamiento, sea con las imágenes o con las palabras. La transparencia del cristal que nos permite ver a su través muestra unas propiedades que no son constantes sino variables. No todo vidrio es translúcido; encontramos vidrios más o menos opacos, coloreados e incluso tratados para constituir en ellos una superficie opaca pero brillante que permita el reflejo, se trata de los espejos. El espejo, que en la antigüedad se conseguía mediante el tratamiento de una superficie metálica bruñida, sería después una de estas modalidades de cristal a cuyo través no es posible ver nada, pero que, por el contrario, refleja en su superficie las imágenes de lo que está fuera. Gilbert Durand ${ }^{4}$ nos habla del espejo entendiéndolo como el símbolo de la translucidez ciega y se podría decir aquí que el espejo simula una translucidez, pero no nos permite ver a su través. Podemos pensar entonces que el espejo remite exactamente a la experiencia contraria a la que hemos venido comentando hasta ahora al vincular el cristal a la transparencia y a la posibilidad de ver a su través, porque la visión del espejo alude a otro tipo de visión: no se trata de permitir ver, sino de provocar la reflexión. Por otra parte, el primer espejo de la humanidad debemos presumir que fue el agua, cristalina y transparente, mansa y profunda, espejo-manantial o espejo-lago que la naturaleza ponía ante la mirada del ser humano al contemplar su reflejo. La fábula de Narciso y Eco tal como la describe Ovidio en Las Metamorfosis, la más conocida de las versiones, viene a ser una matriz de pensamiento que establece, a la base de nuestra cultura, los elementos fundamentales de lo que podríamos considerar toda ulterior estética a través de la metáfora del espejo. En el relato, con sus diferentes versiones y fuentes antiguas, encontramos numerosos elementos cuya impronta los constituye en símbolos de reiterada presencia en la evolución de las culturas y sobre todo de nuestra cultura occidental.

Una simbólica en torno al estatuto ontológico de la imagen nace con el mito de Narciso. En su relato encontramos el espejo ancestral: el agua. En este caso superficie-espejo que refleja una imagen de inmensa belleza. La Belleza es también la materia presente en la fábula de Ovidio sobre la que el mito como fuente de pensamiento pretende hacernos reflexionar. Por un lado sobre la Belleza en sí, la de Narciso, por otro sobre la Belleza reflejada, imagen diferida y diferente, a la vez auténtica en su ser y desdoblada en el reflejo, original y copia, persona y su doble especular. Más allá y al margen de la interpretación del narcisismo en psicoanálisis,

3 Aristóteles: Poética 1457 y y Retórica 1411 b.

4 Durand, G.: Las estructuras antropológicas de lo imaginario. Madrid, Taurus, 1982. 
también da que pensar el mito sobre la función del amor, del Eros, en el ámbito de la creatividad y del arte. El Eros en cuanto fuerza de atracción que moviliza, haciendo de la contemplación algo a la vez estático y dinámico, ni pura pasividad ni actividad pura, sino pura tensión. Y, por último, la transformación en flor, un símbolo a la vez de amor y de belleza, pero aquí también de vida y de muerte ya que el nombre de Narciso tiene su origen en una raíz griega, nárke, de donde procedería narcótico, producto que induce al sueño, a un adormecimiento que simula la muerte.

Para los artistas, nunca ha dejado de inquietar esa relación que se establece con la realidad por medio de las imágenes que plasman en sus obras. Pero esa búsqueda de Belleza, se les antoja por lo general imposible. Y es imposible en cuanto objeto a reproducir, imitar o reflejar en la obra, nos dice el mito, porque radica en la propia imagen que se refleja, le pertenece al ser humano que la contempla. Imposible por tanto hablar de Belleza, saber qué es la Belleza, definir la Belleza contemplada, sin que esté ya en nosotros, ya que el acto de la contemplación de la Belleza no produce conocimiento sino que es un acto de auto-reconocimiento, de reconocimiento de algo que ha de poseerse. Recordemos que la imagen que contempla Narciso es la suya, ignorada, desconocida, irreconocible si no es en virtud de un acto de contemplación. Diríamos que Narciso es ciego para sí mismo, que hay en la contemplación un reducto de ceguera.

\section{Lo positivo y lo negativo de la transparencia}

Es ese reducto de ceguera el que me parece presente con mucha fuerza en la obra que quiero que consideremos: Mi terraza de Roma.

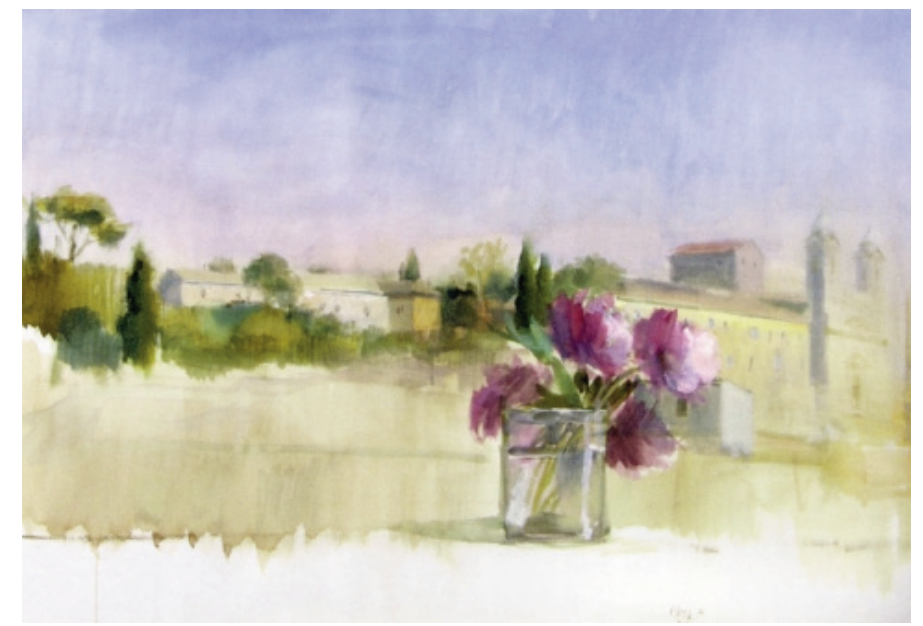

Fig. 2.- Mi terraza en Roma, 1966. Gouache sobre papel. 70 x $100 \mathrm{~cm}$. Colección particular 
Es un Gouache de 70 por 100, que Ramón Gaya pinta en 1966. Curiosamente la terraza no parece ser la preocupación del pintor, apenas unas pinceladas nos evocan las formas y la composición del muro. Si no fuera por el título no repararíamos en la terraza. Sobre el muro un vaso con flores, uno de los muchos que se repiten a lo largo de la obra de Gaya. Hasta aquí lo que podríamos calificar como un primer plano, y al fondo, no ya en un segundo plano sino en la relativa proximidad de una vista de Roma, un paisaje difuminándose en el que conviven árboles, torres de una iglesia, tejados de edificios y un cielo azul, blanquecino de sol.

Se trata, sin duda, de una obra humilde. Nada pretenciosa. Solo una vista parcial de un panorama desde "mi terraza", su terraza de entonces, mi terraza ahora: en la que estoy, desde la que veo. Desde la que veo no solo lo que él vio sino lo que quería que nosotros viéramos ahora. Y me pregunto: qué veo, qué quiero ver, qué quiso él, Ramón Gaya, que viéramos. Porque en mi campo de visión, en su campo de visión, en nuestro campo de visión hay un obstáculo: el cristal transparente, el vaso con las flores.

Como hemos visto, los objetos de cristal, tanto vasos, copas, jarras o espejos, retornan, se repiten como podría repetirse un síntoma, como imágenes síntomas, en este caso de un deseo muy concreto: un deseo de ver, deseo de ver a través, tal y como lo expresa en la entrevista con Nigel Dennis que hemos citado.

Si nos detenemos un instante en esa repetición del cristal podemos extraer varias ideas:

$1^{\circ} \mathrm{El}$ carácter de síntoma, de algo que se repite, que vuelve, retorna porque expresa. En este caso expresa la obsesión por la transparencia. Por aquello que permite ver a su través a la vez que transforma, metamorfosea las cosas, la realidad.

$2^{\circ}$ El valor de la repetición como categoría estética cuyo origen está en el ritual, pero cuya presencia en la escena, en el teatro, hace del espectáculo que se representa y que se contempla un acontecimiento que renueva nuestra relación con los orígenes, con el universo de los símbolos, de un pasado que nos configura y nos determina. En el caso de la pintura de Ramón Gaya la repetición del cristal, de la transparencia, hace de sus pinturas escenas; no naturalezas muertas, como él muy bien aclara en otro momento de su entrevista, sino escenas ritualizadas, y hace de la tarea del pintor una tarea sagrada, transcendente: Pintura no es hacer, es sacrificio, nos dice.

$3^{\circ}$ En el caso de la obra que nos ocupa, Mi terraza de Roma, el vaso de cristal con flores interrumpe la visión. Parece como si Ramón Gaya con esta obra contradijera sus propias explicaciones: de una transparencia que hace ver, pasamos a una transparencia que impide la visión, incluso podríamos decir que molesta, que perturba el espectáculo de una vista de Roma desde su terraza, desde nuestra terraza. El vaso no es ahora la muestra de una transparencia que fascina sino el obstáculo, el punto ciego para ese deseo panorámico de ver. Y así, la transparencia del cristal, que era para nosotros en sus obras un elemento positivo, en esta ocasión se transforma en un elemento negativo, en algo que lejos de permitir la visión la obstaculiza. 
Si Ramón Gaya estuviera aquí presente podríamos preguntarle, hacerle observar que quizá él se contradice en esta obra. Pero no está, y sólo podemos esperar que la pintura hable, que se explique. Ahora bien, estamos intentando romper con ello El silencio del arte, ¿cómo hacer esto posible? El propio pintor procura respondernos: El creador no aspira a la palabra, es decir, al arte, a la obra, sino al silencio; claro que a un silencio vivo, a un silencio de vida, no de muerte, ni siquiera mudo, sino comunicante, a semejanza quizá, del mismo silencio de Dios. ${ }^{5}$

Nada menos que el silencio de Dios. Un silencio que nos sumerge en el desasosiego, que nos angustia, que consigue todo menos tranquilizarnos. En el caso de la pintura de Ramón Gaya él quiere hacernos valorar ese silencio, no como ausencia, sino como enigma, el enigma del arte es así el enigma de algo que tiene que ver con lo sagrado.

En un silencio vivo y comunicante, Mi terraza de Roma, tiene que revelarnos el porqué de ese cambio en la valoración del cristal.

Quizá podamos acudir a algún texto de Ramón Gaya. Pienso en las numerosas veces en las que afronta sin titubeos el hecho de sus contradicciones, porque la contradicción no le perturba: ... a veces a mí me ha gustado contradecirme, y uno aprende mucho contradiciéndose ${ }^{6}$, leemos en una de sus entrevistas. Por tanto, él cuenta con la contradicción como elemento enriquecedor de su pensamiento, como la muestra de un pensamiento proteico, en evolución permanente, inquieto y creador; quizá porque cuando lo que se afirma es el fruto de una reflexión rigurosa, la contradicción es sólo aparente y lo que se nos ofrece es el resultado de un nuevo matiz enriquecedor. Pero más allá de las aparentes contradicciones, pienso que las pistas para comprender ese cambio en la valoración de la transparencia las encontramos en otros lugares, por ejemplo en las reflexiones sobre lo positivo y lo negativo que se recogen en Anotaciones e insistencias 7 :

(...) Lo negativo no nos quita nunca nada, nos da, nos enriquece como acaso no puede enriquecernos lo más positivo (...).

Lo positivo inmediato -la belleza, lo perfecto, el bien- es siempre como un tope, es algo que, a su sola aparición, se detiene y nos detiene; lo positivo no nos lleva a ninguna parte, porque es ya de por sí, final. Lo negativo, en cambio, por terrible que pueda parecer, o incluso, ser, diríase que empieza, que inaugura, que abre vivamente algo ante nosotros; más que un horizonte, eso que abre es como un abismo. Sí, pero es como un abismo... infinito, rico, repleto de bienes profundos, que, poco a poco, habrá que ir descifrando, que ir rescatando.

\footnotetext{
5 Gaya, R.: El silencio. En El silencio del arte. Obra completa, Valencia, Pre-Textos, 2010, p. 76

6 Gaya, R.: - de viva voz, p. 241

7 Gaya, R.: OC., p. 917
} 
Lo positivo es finito y... superficial; lo negativo es infinito y profundo. Lo positivo no es más y no nos da más que eso que está ahi; lo negativo, en cambio, significa otra cosa, otra cosa, otras cosas; lo negativo encierra siempre una significación, o incluso, varias significaciones; lo negativo es siempre como una metáfora-una metáfora oscura y más difícil-de algo... positivo, de algo fatalmente positivo que habita en un fondo último de la realidad.

Lo positivo nos deja muy confiadamente aposentados en un lugar placentero, quieto y un tanto estéril. Lo negativo nos mantiene en pie, desasosegados, en una especie de incomodidad vívida que nos empuja a la vida. ${ }^{8}$

Al mirar Mi terraza de Roma teniendo presentes las reflexiones que acabamos de leer sobre lo negativo, se hace más claro lo que se nos comunica a través de el silencio del arte, escuchamos mejor; podríamos decir que percibimos la significación de la obra. Porque el vaso transparente en medio del muro, interrumpiendo nuestra vista de ese trozo de Roma, que es también el mundo, que es la vida, que es la realidad, alude en este caso a lo negativo que la transparencia quiere mostrar, aquello a lo que la transparencia, todas las transparencias, todos los espejos, todas las variaciones sobre el cristal en la obra de Ramón Gaya, aluden con insistencia obsesiva: el obstáculo-vaso -lo negativo- muestra con toda la fuerza y el vigor posibles la metáfora de la transparencia -lo positivo-, haciendo de ella, a través de esos objetos, algo rotundo, completo, total. Porque aquello que nos hace ver, no nos hace ver todo, ya que la transparencia se abre a un abismo, un abismo infinito donde luz y oscuridad, visión y ceguera conviven.

\section{La escritura y la claridad/transparencia en el pensamiento español}

Juan Gil-Albert, refiriéndose a R. Gaya en El fruto original ${ }^{9}$ nos dice que el de Ramón Gaya “...es el único caso que recuerdo, desde Leonardo, en que un pintor puede, por decirlo así, mojar la pluma y el pincel en el agua transparente del mismo enigma."

Las palabras de Gil-Albert nos sitúan frente al enigma de la creación artística, haciendo del propio Gaya un enigma en cuanto creador. En este caso Gil-Albert alude a la doble vertiente en la que nuestro artista se realiza: la pintura y la escritura. Sabemos que él se define como un pintor que escribe y no nos parece objetable esta visión de sí mismo, pero sabemos también el carácter que en nuestros días podemos atribuir a la escritura, un carácter que más allá de la pura grafía, de la

8 OC., p. 218

${ }^{9}$ Gaya, R.: El fruto original. En $O C$. , p. 855. 
acción de escribir, del enfrentamiento a la página, se manifiesta como pura vivencia, como compromiso ético y por lo tanto como vida. En el caso de Ramón Gaya su escritura viene a ser su compromiso ético con la pintura. Una actividad que va mucho más allá de un ejercicio crítico-ensayístico para convertirse en un habla y una escucha de la mirada.

Esa fascinación por la transparencia de los cristales en los cuadros, cuyo fin es hacer ver a su través el misterio de la realidad, la observamos también en sus escritos. Porque su escritura es tan transparente como sus cristales. Con esto no quiero decir que sea una escritura fácil, por el contrario tiene esa dificultad tramposa de lo aparentemente sencillo, llano, sin pedanterías académicas ni recursos artificiosos. Y en eso Ramón Gaya permanece fiel a una línea de raigambre netamente española en la que los pensadores buscan más la claridad diáfana del cristal que la artificiosidad importada de otros espacios culturales. Ya en el Diálogo de la lengua Juan de Valdés nos dice:

Para deziros la verdad, muy pocas cosas observo, porque el estilo que tengo me es natural, y sin afetatión ninguna escrivo como hablo; solamente tengo cuidado de usar de vocablos que sinifiquen bien lo que quiero dezir, y dígolo quanto más llanamente me es possible, porque a mi parecer en ninguna lengua stá bien lafetatión. 10

Y más adelante:

Con deciros esto pienso concluir este razonamiento desabrido: que todo el bien hablar castellano consiste en que digáis lo que queréis con las menos palabras que pudiéredes, de tal manera que, explicando bien el conceto de vuestro ánimo y dando entender lo que queréis dezir, de las palabras que pusiéredes en una cláusula o razón no se pueda quitar ninguna sin ofender o a la sententia della, o al encarecimiento, o a la elegantia. ${ }^{11}$

Ortega y Gasset manifiesta con sabia rotundidad que la claridad es la cortesía del filósofo y recordemos la firmeza con la que Antonio Machado le enseña el valor de la claridad en el lenguaje poético al alumno de Juan de Mairena, al pedirle que ante la frase alambicada: Los eventos consuetudinarios que acontecen en la rúa..., ponga aquello en lenguaje poético, con el conocido resultado de: lo que pasa en la calle.

La claridad en los textos de Ramón Gaya es la cortesía de un pintor que escribe. Y sobre todo que escribe fascinado por la transparencia. Porque Ramón Gaya también quiere hacer ver a través de su escritura, es decir, hacer ver más allá de las palabras, trascendiendo. Cuando estudiamos sus textos, y digo estudiamos, no simplemente leemos, quiero, por tanto, decir con ello que los pensamos, que los pone-

10 Valdés, J. de: Diálogo de la lengua. (Edición de José Enrique Laplana). Barcelona, Crítica, 2010, p. 238.

11 Ídem, p. 242. 
mos en relación con otros autores, que los confrontamos con otras teorías estéticas, poéticas o de cualquier otra índole, nos precipitamos en el abismo de la transparencia, en ese espacio claro y profundo, sin final, pero completo, que no nos permite detenernos.

Pensando a partir del arte, como artista, es decir, como creador, yo entiendo que Ramón Gaya nos ofrece una estética abierta, no sistemática, pero sí rigurosa. Sus tesis son contundentes y lo que buscan es dar a pensar, proponiendo aquello que ha llevado a cabo con su pintura: una estética de la mirada desnuda, enigmática, rigurosa. Sin fuegos de artificio, sin concesiones. Una estética que se expone de manera a veces abrupta, que no busca definir, sino redefinir. Que prefiere el observar lento y minucioso, en lugar del golpe de vista rápido y concluyente. Lo que pinta se piensa en sus textos y lo que escribe se plasma en sus obras.

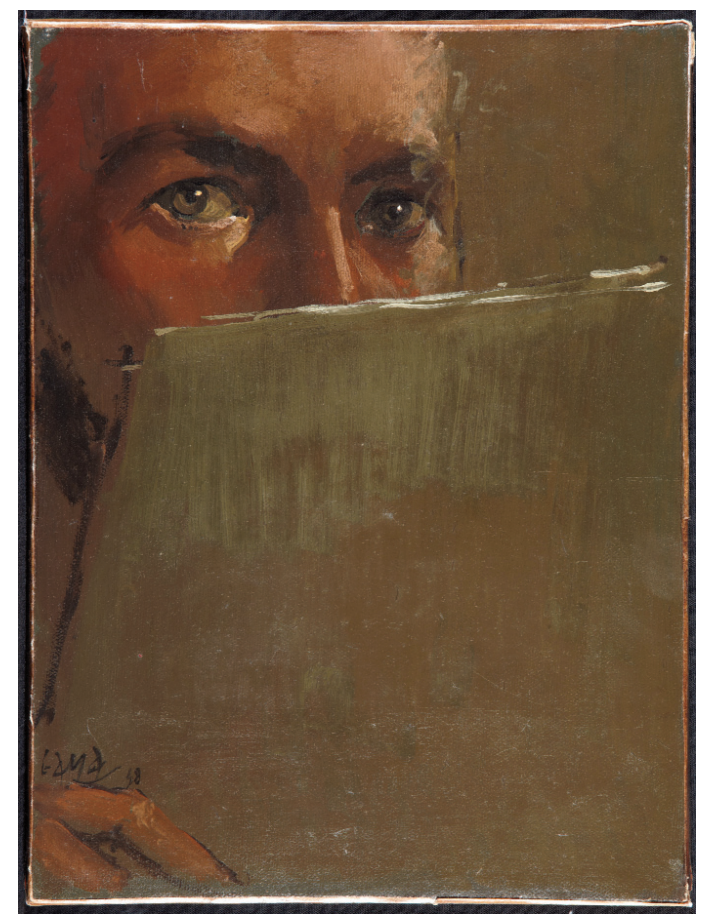

Fig. 3.- Autorretrato, 1948. Óleo sobre lienzo. 30,5 x $23 \mathrm{~cm}$.

Quizá en este autorretrato, que data de 1948 y que realiza en México, se pueda ya vislumbrar que desde muy pronto esa tensión de la mirada es protagonista de toda la obra; una mirada, la del pintor, escrutadora del enigma al tiempo que enigmática ella misma, transparente a la vez que fascinada por la transparencia. En el cuadro, lo que el autor oculta es la mitad del rostro que corresponde al habla. Mirada, por tanto, que se parapeta en el silencio, "el silencio del arte". Diríamos que 
se trata de un cuadro programático porque la esencia de la trayectoria creadora de Ramón Gaya, tanto en sus escritos como en sus pinturas y dibujos hasta el final de su vida, se manifiesta en él. En el cuadro, solo, el pintor mira, se contempla y nos mira. Es la mirada del Narciso mítico que se renueva y se repite eternamente ante el arte, la belleza y la creatividad; una mirada que es, sobre todo, mirada de reconocimiento, porque en este caso el pintor busca fuera, en la transparencia, lo que su mirada conlleva, lo que ya muestra de manera implícita: la transparencia. Por otra parte, sus ojos "dicen", expresan, lo que expresará la pintura, pero la boca, oculta por el soporte, desaparece y queda muda, subrayando el silencio, el silencio del arte. Un silencio que Ramón Gaya nos pide que escuchemos a través de sus variaciones sobre el cristal.

\section{El sentimiento de la pintura}

Siempre que pretendemos entender el enigma de la pintura se presentan ante nosotros tres ámbitos vinculados al sentido que buscamos aclarar. En el ámbito semiótico, la pregunta por el sentido de la pintura tiene que ver con la semiosis, con el significado, sêma. Cuando nos instalamos en el ámbito estético, la pregunta por lo estético interroga al mundo de la sensación, aisthesis; mientras que el sentido de la pintura también se nos ofrece vinculado a un pathos, al mundo del sentimiento. George Didi-Huberman ${ }^{12}$ recuerda que Leonardo Davinci en sus Profezie utiliza la palabra sentimento para acoger estos tres ámbitos, y nos resulta sorprendente observar que también Ramón Gaya se aventura a reflexionar sobre El sentimiento de la pintura ofreciendo a sus lectores un texto en el que se van desgranando a partir de la palabra sentimiento estos diversos sentidos. Ya en las primeras páginas de esta obra aparece, programáticamente expuesto, el conflicto en torno a la pintura, la dificultad de movernos a través de esos caminos que se entrecruzan a modo de un intrincado laberinto, el laberinto en el que se pierde o por lo menos deambula, quien pretende conocer el enigma de la pintura:

Se pensó que el arte era una especie de comentario más o menos agudo, penetrante, intenso que unas personas especialmente dotadas -los artistas- hacen del espectáculo de la realidad. 13

Gaya comienza aquí aludiendo al intento de la crítica por explicar el "sentido" de las obras de arte a lo largo de la historia: cada vez que ha surgido la necesidad de "explicar" la pintura, el "comentario" ha servido para hacer del artista un ser

12 Didi-Huberman, G.: La pintura encarnada. Valencia, Pre-Textos, 2007, p. 9

13 Gaya, R.: El sentimiento de la pintura, O.C. p. 32. 
superior, alguien capaz de explicar lo inexplicable, lo profundo, el enigma de la creación. Gaya, discrepando, aborda el tratamiento del tema de la pintura moviéndose en el ámbito del significado, en el ámbito semiótico. La pregunta nace en esta primera instancia, en este primer desarrollo del tema, como pregunta por el significado de un arte que no habla, que no expresa pensamientos con palabras, que podría decirse que nos hace dudar sobre si en realidad la pintura piensa.

Inmediatamente después continúa diciendo:

Ni siquiera es, como supone Bergson, una visión más directa de la realidad. ${ }^{14}$

Ahora el "sentido" de la pintura es para Gaya, algo que tampoco se aclara si buscamos comprenderlo a partir de una "visión más directa de la realidad" y por lo tanto de una sensación del artista, aisthesis, por muy depurada, exquisita, compleja, o misteriosa que resulte. Está entonces Gaya trasladándonos del ámbito del significado, al de la sensación, del ámbito semiótico, al estético. Pero su conclusión incorpora el último aspecto, el que completa y complica a la vez las explicaciones en torno a la pintura:

El arte es realidad, el arte es vida él mismo y no puede, por lo tanto, separarse de ella para contemplarla; el arte no es otra cosa, no puede ser otra cosa, que vida, carne viva, aunque, claro, no sea nunca mundo. 15

Ahora Gaya no habla ya de pintura, cambia de perspectiva, no quiere hablarnos sólo de la pintura, sino de aquello que hace de la pintura un arte. Con el comentario y la visión, desde lo semiótico y lo estético, la comprensión del arte no se alcanza. Pero entender el arte como "carne viva", nos conduce a comprenderlo no sólo como el producto de un cuerpo, como simplemente carne, sino como el producto de un cuerpo, el humano, viviente, y, por ello mismo, sintiente. Un cuerpo dotado de la posibilidad de sentir y de sentirse, de "sentimiento", nos lleva a concebir el sentido de la pintura con Ramón Gaya como algo impensable sin el pathos, sin la experiencia del sentimiento humano. Ser pintor -nos dice- no es gustar de lo pictórico (...) sino que ser pintor no es más que una forma como otra de ser hombre, una de las encarnaciones posibles del hombre. 16

Parecería que sólo ese tercer ámbito, el del sentimiento, el del pathos, dota a la pintura de la posibilidad de ser verdadero arte, de ser arte auténtico. Pero un poco más adelante y después de comentar el cuadro de Carpaccio, Las cortesanas, como una apoteosis del primitivismo, continúa diciéndonos:

\footnotetext{
14 Ibídem

15 Ibídem

16 Ídem, p. 36
} 
Ahora veía, arrancado de un solo manantial primero, dos brazos de agua grandes: uno, el del sentimiento; otro el de la expresividad.

Para concluir páginas adelante:

En arte elogiamos mucho la pasión... La pasión es quizá la parte positiva, la parte valiosa de una desesperación.

Para él Giotto inaugura una época dotando a la pintura de expresividad y Carpaccio la cierra incorporando el sentimiento, acabando con un periodo que Ramón Gaya denomina de "sordera", en que el silencio y la inmovilidad "comunican". Sentido (aisthesis), significado (sema) y sentimiento (pathos) son las nociones de un laberinto, el del arte, que estableciendo una continuidad desde Leonardo hasta Ramón Gaya, reaparecen, actualizándose cuando la reflexión sobre la pintura busca tomar de nuevo conciencia de las relaciones entre el arte y la vida.17

\section{Anónimo y doble firma: de la tachadura del nombre propio a su duplicación}

Una de las constantes que se pueden percibir a lo largo de lo que algunos autores han venido calificando como una subversión cultural ${ }^{18}$ que abarca desde la irrupción del pensamiento de Nietzsche hasta estas primeras décadas del segundo milenio es la crisis del sujeto, de ese yo pensante que desde Descartes garantizaba los vínculos entre pensamiento y existencia. La propia figura del filósofo, enmascarado tras sus diversos alter ego -Dionisos, el Crucificado, Zaratustra, o "todos los nombres de la historia"-, adelanta un movimiento expansivo que no sólo en la literatura y en la filosofía sino también en las artes visuales va a nacer con la necesidad de mostrar la debilidad y la fragmentación de aquel sujeto cartesiano tan firmemente establecido. El autor, el dueño del discurso o de la obra, no consigue reconocerse en sus escritos y necesita crear personajes, heterónimos diríamos en el caso de Pessoa, alter ego ficcionales en el caso de Kafka por medio de sus respectivos K, el agrimensor de El Castillo, por ejemplo, que sean capaces de encarnar las múltiples facetas que una biografía puede llegar a hacernos vivir. Ese escritor que se vive en sus personajes es, a la vez, uno y múltiple, idéntico y distinto, semejante y diferente. Es alguien que se sabe en proceso, en tránsito, que apenas se reconoce en el joven que fue o en el viejo que ha llegado a ser. En 1868 Isidore Ducasse firma sus escritos bajo el seudónimo de Conde de Lautréamont, mientras que sus poesías apa-

17 Gaya, R.: El sentimiento de la pintura, pp. 38 y ss.

18 Schajowicz, L.: Los nuevos sofistas. La subversión cultural de Nietzsche a Beckett. Puerto Rico, Ediciones de la Universidad de Puerto Rico, 1979. 
recen con su firma auténtica en 1870. Un yo narrativo firma Los cantos de Maldoror y un yo poético sus versos, haciendo de su corta vida un modo de exponer y de asumir esa fragmentación que pugna por salir a la luz. El nombre propio se borra para dejar paso a un escritor ficticio, dignificado, ennoblecido, a la vez máscara que oculta y nomenclatura que designa e identifica, legitimando con su nombre aristocrático la tarea del creador, haciendo que su nombre auténtico y su obra sucedan al escritor ficticio. El autor no será, en consecuencia, verdadero autor más que después de haber conseguido una obra que lo ha convertido en escritor. Tal y como afirma Freud, el artista no es padre sino hijo de sus obras.

En el caso de la cultura española, los ejemplos de ese sentimiento de época no son escasos. Ortega y Gasset nos presenta al Doctor Vulpius, alemán y profesor de filosofía, y en el que reconocemos la encarnación del nórdico que manifiesta que habita en su interior; a don Rubín de Cendoya, místico español que nace en Córdoba y viaja por Castilla; a Olmedo, un perspicaz banquero, además de experimentado hombre de mundo, y, por último, a Gaspar Mestanza, interesado por la política y las cuestiones sociales. También Eugenio d'Ors crea su Octavio de Romeu, y señala la lista de contemporáneos que ilustran la búsqueda de otros yoes literarios: José Martínez Ruíz, Azorín, el Silvestre Paradox de Baroja, Valle Inclán y su Marqués de Bradomín. Antonio Machado se inventa sus complementarios, mostrando con ello la necesidad no de heterónimos, de personajes de distintos nombres pero semejantes desasosiegos, sino de seres figurados que utiliza para mostrar las múltiples facetas que componen y complementan al individuo integral. Mediante la aparición de seudónimos, heterónimos o complementarios podemos decir, en consecuencia, que aflora una profunda inquietud ante un uso del nombre propio que tanto identifica como aliena, al configurar fuera de nosotros un sujeto que se emancipa y vive su propia existencia 19 .

Parecería, no obstante, que el fenómeno en cuestión se limitara al hecho literario. Sin embargo, encontramos en Ramón Gaya elementos que nos recuerdan, con características muy particulares, este tratamiento del nombre propio, de la autoría o de la firma. Me parece sobremanera interesante señalar aquí algunos ejemplos que nos sitúan ante la necesidad de pensar, si no los motivos, al menos el efecto que puede tener la manera de abordar la peculiaridad de la firma en la mejor comprensión de su obra.

19 Para un mayor tratamiento del tema ver A. Ma Leyra, Heterónimos y complementarios. Los personajes de Ortega en el escenario europeo. En Ortega y Gasset pensatore e narratore dell'Europa. Milán, Cisalpino, 2001. 


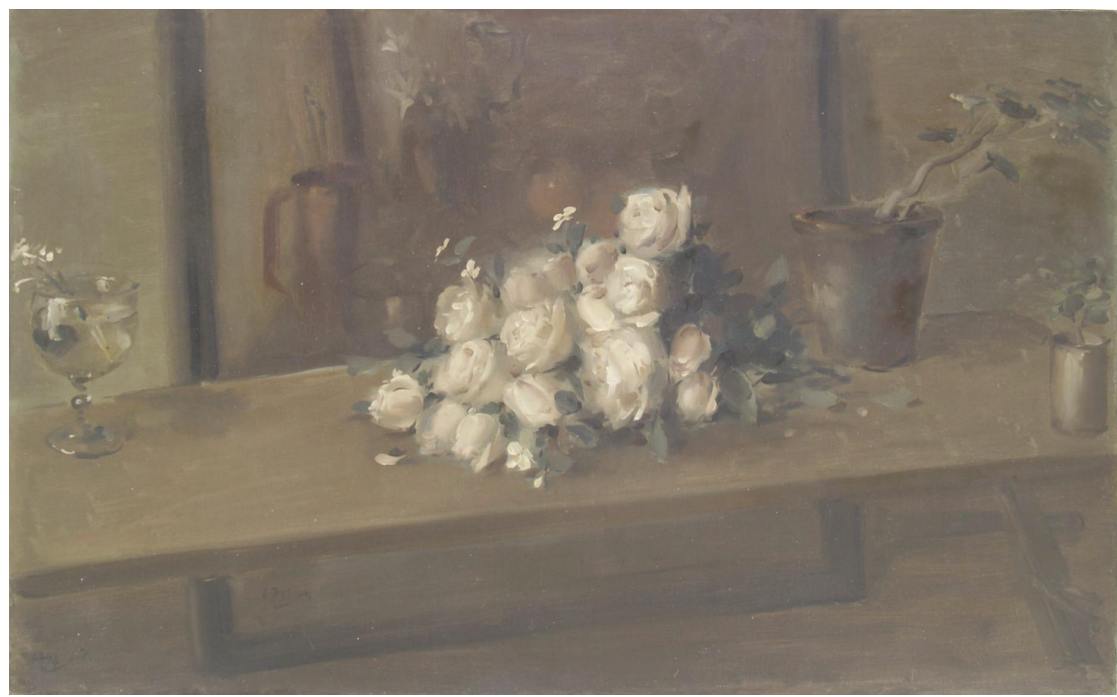

Fig. 4.- Cuadro con doble firma, 1959. Óleo, colección particular

En un óleo de 1959 nos sorprende encontrarnos con dos firmas del autor. La obra nos muestra un cuadro de Gaya que reproduce un cuadro de Gaya. En este caso no nos encontramos ante una muestra más de cuadro dentro del cuadro, Ramón Gaya insiste profusamente como es sabido en incluir imágenes de la pintura universal en sus cuadros. Más bien nos referimos aquí al hecho de que Ramón Gaya opta por pintar un cuadro en el que se nos muestra una obra suya precedente y, ante ella una sencilla mesa de madera que presenta una copa de cristal transparente con jazmines a la izquierda, un ramo de rosas blancas en el centro, y unas plantas en sus macetas a la derecha. Los dos cuadros están firmados, el representado, abajo a la izquierda, el original, también a la izquierda y más abajo. Toda la disposición de la obra recuerda un sencillo y modesto altar en el que, las flores se ofrendan en un renovado homenaje, esta vez al propio autor, a la propia obra. Homenaje rubricado por esa doble firma que, en esta ocasión no oculta al autor sino que reafirma al signatario, como si Ramón Gaya dijese a quien contempla su cuadro: ésta es mi pintura, éste es mi arte, éste es mi homenaje. 


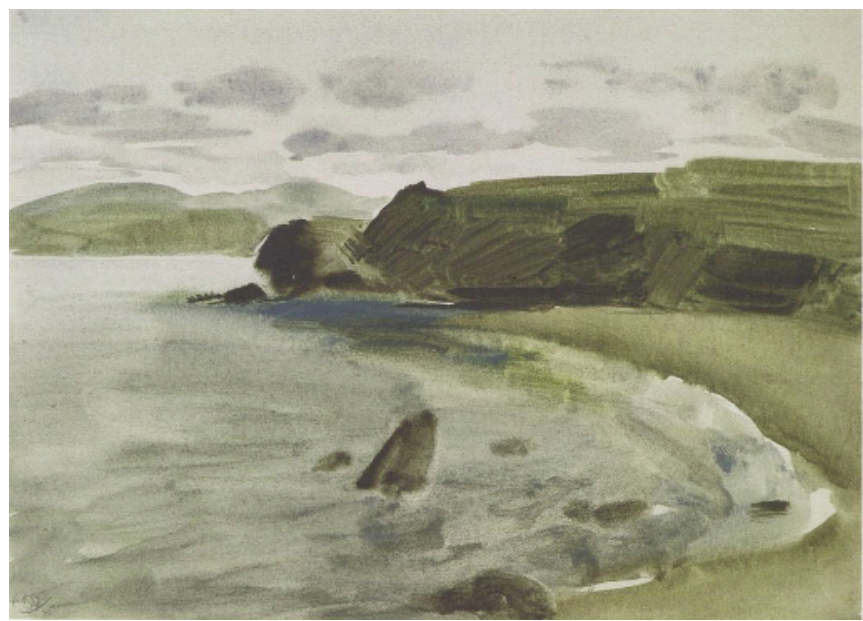

Fig. 5.- Atardecer en Acapulco, 1945. Gouache. 23 x $30 \mathrm{~cm}$.

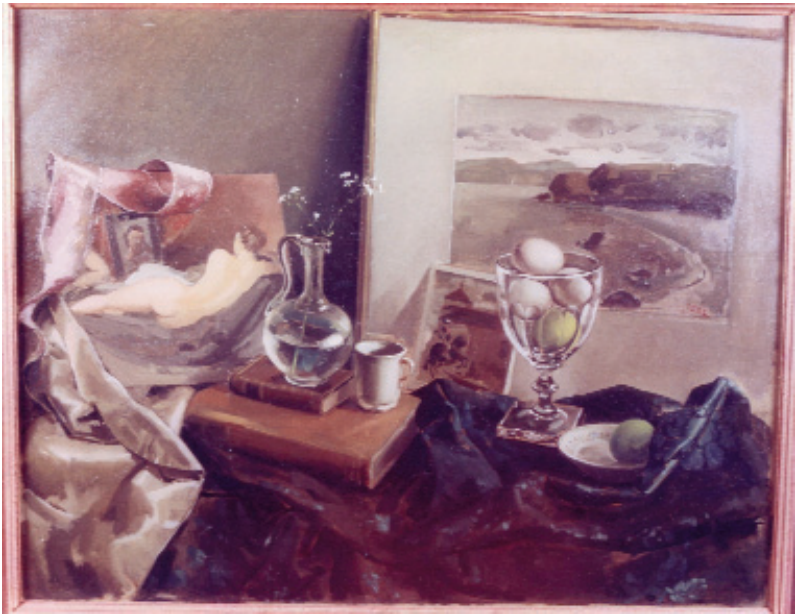

Fig. 6.- Homenaje a "Atardecer en Acapulco", 1945. Óleo

A esta interpretación nos anima el hallazgo de otros dos cuadros, ambos fechados en 1945: Atardecer en Acapulco y Homenaje a "Atardecer en Acapulco". Su existencia nos hace pensar en la manera en la que el autor los valora y con ello valora su tarea. Primero Atardecer en Acapulco, la pintura, la obra que plasma una hora y un paisaje, tiempo y naturaleza bajo la mirada del artista. Después, uno de sus "altarcitos", como los denominó Concha de Albornoz, uno de sus sagrados reconocimientos a la pintura, Homenaje a "Atardecer en Acapulco". En este cuadro conviven libros, una evocación de la Venus del espejo de Velázquez, una jarra transparente, una copa, también transparente, repleta de huevos, y el cuadro de Gaya titu- 
lado Atardecer en Acapulco. El pintor intuye que su tarea creadora comparte la aspiración de todo gran artista a la transparencia, a la veneración de los modelos, y, a su vez, aspira a convertir sus propias obras en modelos.

Resulta siempre aventurado intentar hacer hablar a la pintura, saltarnos el silencio del arte, pero el propio Gaya nos invita a ello, a reconocer algo vivo en todos y cada uno de sus cuadros, y esa vida nos parece en esta ocasión que está ligada a la necesidad de reconocimiento y de valoración para su tarea intemporal; a la exigencia de hacer de sus obras esos espacios por los que el arte transita, esos abismos a los que el pintor se asoma y nos convoca como feligreses y como acompañantes. 